\title{
Peningkatan Spiritualitas melalui Wisata Religi di Makam Keramat Kwitang Jakarta
}

\author{
Nur Indah Sari \\ Universitas Negeri Jakarta \\ nurindahsari_iai13@mahasiswa.unj.ac.id \\ Firdaus Wajdi \\ Universitas Negeri Jakarta \\ firdaus.wajdi@unj.ac.id \\ Sari Narulita \\ Universitas Negeri Jakarta \\ sari-narulita@unj.ac.id
}

\begin{abstract}
This study aims to describe and analyze religious tourism as an effort to increase the spirituality of visitors or pilgrims in the Tomb of Kwitang Jakarta. Increased spirituality is a process of change from bad to better by constantly carrying out God's command and away from God's prohibition consistently with the guidance of the values of faith to recognize and understand feelings Self, others, self-motivated, and able to manage emotions in relation to others. Meanwhile, the Sacred Tomb of the Mosque Ar-Riyadh Kwitang is one of the famous religious tourism sites in Jakarta, which is visited by many individuals and groups. This research uses descriptive qualitative approach with the respondent of the sacred grave of Masjid Ar-Riyadh Kwitang Jakarta. This research produces some important points about the process of improving spiritual intelligence through religious tourism.
\end{abstract}

Keywords: Spirituality, Religious Tourism, Sacred Grave Kwitang.

\begin{abstract}
Abstrak
Penelitian ini bertujuan untuk mendeskripsikan dan menganalisis wisata religi sebagai upaya untuk peningkatan spiritualitas pada pengunjung atau peziarah di Makam Keramat Kwitang Jakarta. Peningkatan spiritualitas merupakan suatu proses perubahan dari yang tidak baik menjadi lebih baik dengan senantiasa melaksanakan perintah dan menjauhi larangan Allah secara konsisten dengan bimbingan nilai-nilai rukun iman untuk mengenali dan memahami perasaan sendiri, orang lain, memotivasi diri, serta mampu mengelola emosi dalam berhubungan dengan orang lain. Sedangkan, Makam Keramat Masjid Ar-Riyadh Kwitang merupakan salah satu tempat wisata religi terkenal di DKI Jakarta, yang banyak dikunjungi oleh masyarakat secara perseorangan maupun kelompok. Penelitian ini menggunakan pendekatan kualitatif deskriptif dengan responden pengunjung makam keramat Masjid Ar-Riyadh Kwitang Jakarta. Penelitian ini menghasilkan beberapa poin penting mengenai proses peningkatan kecerdasan spiritualitas melalui wisata religi.
\end{abstract}

Kata Kunci: Spiritualitas, Wisata Religi, Makam Keramat Kwitang. 


\section{A. Pendahuluan}

Tingkat spiritualitas setiap orang berbeda-beda dan seringkali mengalami naik turun. Ketika seseorang mengalami kenaikan tingkat spiritualitas dalam dirinya mereka merasakan ketenangan jiwa, yaitu mampu menyesuaikan diri dalam berbagai keadaan, terhindar dari penyakit kejiwaan, mampu menghadapi setiap masalah, serta dapat memanfaatkan potensi yang ada dalam diri dengan sebaik-baiknya. ${ }^{1}$ Sedangkan Ketika tingkat spiritualitas menurun maka akan menimbulkan kehampaan hati, yaitu ketidakingatan akan tujuan hidup yang sebenar-benarnya di dunia. Biasanya hal tersebut dapat menimbulkan sifat-sifat negatif seperti nakal, pendusta, suka mengganggu dan menganiaya orang lain, serta menyinggung juga menyakiti perasaan orang lain. ${ }^{2}$

Pada kenyataannya, memang tidak sedikit umat islam di Jakarta yang dapat dilihat masih kurangnya nilai-nilai spiritualitas dalam dirinya, baik dalam cara beribadahnya, hati dan perasaannya, serta budi pekertinya. Misalnya, dalam beribadah tidak sedikit umat islam yang belum bahkan tidak melaksanakan perintah-Nya, tidak sedikit pula umat islam yang memiliki rasa iri, hasad, dengki dan sebagainnya dalam hati mereka, serta tidak sedikit pula umat islam yang sering menyakiti sesama manusia dengan perilakuperilakunya yang kurang bahkan sangat tidak baik.

Seperti dapat dilihat dan diketahui perbuatan-perbuatan umat islam yang dapat dikatakan rendahnya tingkat spiritualitas tersebut diantaranya, korupsi, kecurangan politik, membunuh, menganiaya, memperkosa, mencuri (mengambil yang bukan haknya), saling mengadu domba (namimah), berbohong, mudah menghakimi orang lain, selalu berprasangka buruk pada orang lain, dan sebagainnya. Padahal telah diketahui bahwa perbuatan-perbuatan seperti itu sangat merugikan bangsa, negara, orang lain bahkan dirinya sendiri.

Islam tidak membolehkan umatnya dalam keadaan kehampaan hati karena dapat menimbulkan berbagai penyakit kejiwaan yang dapat menyebabkan kesengsaraan atau kemenderitaan. Islam menginginkan agar umatnya senantiasa dalam keadaan jiwa yang tenang supaya dapat melaksanakan tugas serta kewajiban selaku manusia dengan sebaikbaiknya di dunia dan bekal akhirat kelak. ${ }^{3}$

Biasanya untuk mampu meningkatkan nilai spiritualitas dalam diri yaitu melalui ritual keagamaan. Ada beberapa cara ritual keagamaan yang sering dilakukan umat islam,

\footnotetext{
${ }^{1}$.Muhammad Isa Selamat, Penawar Jiwa \& Pikiran, (Jakarta : Kalam Mulia, 2005), h. 5

${ }^{2}$.Muhammad Isa Selamat, Penawar Jiwa \& Pikiran, (Jakarta : Kalam Mulia, 2005), h. 5

${ }^{3}$.Muhammad Isa Selamat, Penawar Jiwa \& Pikiran, (Jakarta : Kalam Mulia, 2005), h. 6
} 
diantarannya yaitu dengan qiyamul lail untuk mendirikan sholat tahajjud, melaksanakan puasa sunnah, dan bahkan berziarah ke makam-makam Waliyullaah dengan memanjatkan do'a untuk para Wali Allah serta mengharapkan rahmat dan keberkahan dari Allah SWT.

Dari beberapa bentuk cara ritual keagamaan yang banyak dilakukan umat islam, tidak sedikit yang memilih untuk berziarah ke makam Waliyullah sebagai alternatif utama dalam meningkatkan nilai spirituslitas di kehidupannya, dan banyak umat islam yang mencari jati dirinya yaitu dengan berziarah ke makam Waliyullah. Karena mereka beranggapan bahwa waliyullah adalah wali Allah di muka bumi yang memiliki sifat dan sikap yang patut diteladani dan dianjurkan untuk berziarah ke makamnya. Oleh Karena itu, berziarah ke makam para wali Allah sebagai bentuk ritual keagamaan yang banyak diminati umat Islam.

Berziarah ke makam para wali Allah kini bukan lagi sebagai ritual keagamaan kuno yang hanya sebagian kecil umat Islam saja yang melaksanakan. Akan tetapi, pada saat ini banyak umat islam di Jakarta yang melakukan ziarah ke makam-makam para wali Allah yang dikenal dengan wisata religi (keagamaan). Sehingga berziarah sudah masuk dalam kategori jenis wisata.

Menurut pandangan Al Qurean wisata diambil dari kata siyahah yang secara populer diartikan wisata, kata itu mengandung arti penyebaran, terbentuk dari kata sahat yang berarti lapangan yang luas. Wisata religi dijelaskan dalam Al Qurean surat Yusuf 109-111. ayat ini menjelaskan perjalanan wisata yang bertujuan untuk memperoleh pelajaran dan ibrah. ${ }^{4}$

Wisata religi yang dimaksud bukan hanya bersenang-senang dan mencari hiburan saja, tetapi yang lebih penting adalah memperluas wawasan untuk menyaksikan ayat-ayat kebesaran Allah yang tersebar di bumi ciptaan-Nya ini, seperti mengunjungi tempat atau makam orang saleh sebagai wisata rohani atau wisata spiritual. Wisata rohani atau tamasya spiritual bukan hanya keindahan lahiriah tapi juga ketenangan batiniah yang dapat dinikmati.

Melalui wisata religi (keagamaan) diharapkan mampu menjadi upaya untuk meningkatkan nilai spiritualitas dalam diri seseorang. Akan tetapi, nilai spiritualitas tersebut tidak hanya sebatas ditingkatkan saja melainkan juga harus dipelihara serta dijaga yakni dalam hal kualitas beribadah, hati dan perasaan, serta budi pekerti yang baik.

\footnotetext{
${ }^{4}$.Departemen Agama RI, (Jakarta : 1994), hh. 365-367
} 
Berdasarkan hal tersebut, peneliti ingin melihat bagaimana peningkatan kesadaran spiritualitas melalui wisata religi di Makam Keramat Kwitang Jakarta. Pembahasan mengenai penelitian ini akan dibahas di bab selanjutnya.

Penelitian ini didasarkan pada suatu rumusan masalah yaitu "Bagaimana Meningkatkan Spiritualitas melalui Wisata Religi pada Pengunjung Makam Kramat di Kwitang Jakarta?”, untuk membantu pengumpulan data dan analisis hasil penelitian, maka rumusan besar tersebut diturunkan ke dalam beberapa pertanyaan pembantu sebagai berikut : Apakah dengan wisata religi dapat meningkatkan spiritualitas pengunjung atau peziarah Makam Keramat Kwitang Jakarta?, Bagaimana wisata religi dapat meningkatkan spiritualitas pengunjung atau peziarah Makam Keramat Kwitang Jakarta?, dan Bagaimana peningkatan spiritualitas yang diperoleh pengunjung atau peziarah melalui wisata religi ke Makam Keramat Kwitang Jakarta?

Penelitian ini bertujuan untuk mendeskripsikan dan menganalisis penanaman nilai spiritualitas melalui wisata religi pada pengunjung makam kramat di kwitang Jakarta. Tujuan di atas dapat dicapai melalui tujuan-tujuan antara lain, yaitu : Mengetahui dapat ditingkatkannya spiritualitas melalui wisata religi, mengetahui prosesi kegiatan wisata religi yang dapat meningkatkan spiritualitas pada pengunjung atau peziarah, dan mengetahui sejauh mana spiritualitas dapat meningkat melalui wisata religi.

\section{B. Metode Penelitian/Kajian}

Penelitian ini menggunakan metode kualitatif. Karena dengan metode kualitatif peneliti dapat memperoleh data secara terperinci tentang keadaan-keadaan nyata yang ditimbulkan pada orang-orang serta perilakunya yang dapat diamati kemudian dinyatakan dalam bentuk kalimat atau kata-kata dan gambar.

Peneliti melakukan penelitian selama dua bulan dari bulan April sampai dengan bulan Mei 2017. Peneliti melakukan beberapa aktifitas yang dilakukan peziarah di Masjid Kwitang untuk mendapatkan hasil deskripsi dan analisis mendalam tentang peristiwaperistiwa yang dialami oleh peziarah. Peneliti juga mengamati secara mendalam tingkah laku yang dilakukan oleh peziarah.

Peneliti melakukan penelitian wisata religi yang berada di daerah Jakarta Pusat yaitu Makam Keramat Masjid Ar-Riyadh Kwitang dengan responden para peziarah Makam Keramat tersebut. Peneliti mendeskripsikan setiap peristiwa yang terjadi di lapangan seperti aktifitas spiritual dan kebiasaan yang dilakukan oleh para peziarah. 
Teknik pengumpulan data yang digunakan dalam penelitian ini yaitu observasi, wawancara, dan dokumentasi. Tahapan dalam proses analisis data peneliti menggunakan tiga tahapan yaitu mendeskripsikan, menganalisis, serta menginterpretasikan hasil pebelitian yang telah dilakukan terhadap para peziarah Makam Keramat Masjid Ar-Riyadh Kwitang dalam rangka mengetahui peningkatan kecerdasan spiritualitas diri responden melalui wisata religi tersebut.

\section{Hasil dan Pembahasan}

\section{Peningkatan Spiritualitas}

Menurut KBBI peningkatan berarti proses, cara, perbuatan meningkatkan (usaha, kegiatan, dan sebagainya). ${ }^{5}$ Menurut Adi S peningkatan atau meningkatkan berasal dari kata tingkat, yang berarti lapis atau lapisan dari sesuatu yang membentuk susunan. Tingkat juga dapat berarti pangkat, taraf, dan kelas, sedangkan peningkatan berarti kemajuan yang dapat digambarkan dengan perubahan dari keadaan atau sifat yang negatif berubah menjadi positif. $^{6}$

Priatno menerangkan bahwa spiritualitas adalah menyembah dan mengabdi kepada Allah serta hidup selaras dengan ajaran Allah yang dibawa Rasul-Nya. Orang yang menjalani spiritualitas secara konsisten adalah orang yang beriman, yakni orang yang selalu berpegang teguh pada tali Allah. ${ }^{7}$

Peningkatan spiritualitas adalah suatu proses kemajuan atau perubahan yang dilakukan seseorang menuju kepada perubahan keadaan maupun sifat yang lebih baik atau positif dari keadaan maupun sifat yang negatif atau tidak baik sebelumnya. Yakni senantiasa menyucikan hati dengan menyembah dan mengabdi kepada Allah serta selalu melaksanakan perintah-Nya dan menjauhi larangan-Nya secara konsisten yang selalu berpegang teguh pada tali Allah.

Sedikit berbeda Ary Ginanjar Agustian mendefinisikan spiritualitas dengan Emotional Spiritual Quotient (ESQ) sebagaimana yang dikutip oleh Amal Al Ahyadi dalam Skripsinya ESQ Menurut Ary Ginanjar Agustian dan Relevansinya dengan Pengembangan Kompetensi Spiritual dan Kompetensi Kurikulum 2013: Emotional Spiritual Quotient (ESQ) sebagai sebuah kecerdasan yang meliputi emosi dan spiritual

${ }^{5}$. Pusat Bahasa, KBBI, (Jakarta: Balai Pustaka, 2007).

6 . Artikel; Pengertian Peningkatan Menurut Para Ahli, diakses dari http://www.duniapelajar.com/2014/08/08/pengertian-peningkatan-menurut-para-ahli/ pada tanggal 01/06/2017 06.25 WIB

7. Priatno H. Martokoesoemo, Spiritual Thinking, (Jakarta: Mizania, 2007) h. 46 
dengan konsep universal yang mampu menghantarkan pada predikat memuaskan bagi dirinya dan orang lain, serta dapat menghambat segala hal yang kontradiktif terhadap kemajuan umat manusia. ${ }^{8}$

Pemikiran Ary Ginanjar Agustian mengenai Emotional Spiritual Quotient (ESQ) didasari pada nilai-nilai ihsan, rukun iman, dan rukun islam. Selain sebagai petunjuk ibadah bagi umat islam, pokok pikiran nilai-nilai ihsan, rukun iman dan islam tersebut juga dapat memberikan bimbingan untuk mengenali dan memahami perasaan diri sendiri, perasaan orang lain, memotivasi diri, mengelola emosi dalam berhubungan dengan orang lain. ${ }^{9}$

Nilai-nilai yang mendasari meliputi pada nilai-nilai ihsan, rukun iman, dan rukun islam. Akan tetapi, dalam penelitian ini hanya mengambil nilai yang berlandaskan pada rukun iman. Terdapat enam prinsip yang berorientasi pada rukun iman untuk dijadikan acuan dalam membangun ESQ seseorang diantaranya : Sifat yang terkandung pada prinsip dasar atau prinsip beriman kepada Allah diantaranya memiliki kepercayaan diri tinggi, integritas kuat, sikap bijaksana, memiliki motivasi tinggi. Kemudian, sifat yang terkandung pada prinsip kepercayaan atau prinsip beriman kepada malaikat diantaranya memiliki tingkat kualitas diri tinggi, komitmen kuat, suka memberi, suka menolong, dan sikap saling percaya. Selanjutnya, sifat yang terkandung pada prinsip pembelajaran atau prinsip beriman kepada kitab Allah diantaranya memiliki kebiasaan membaca buku dan membaca situasi dengan cermat, berpikir kritis dan mendalam, selalu mengevaluasi pemikirannya, bersikap terbuka. Kemudian, sifat yang terkandung pada prinsip kepemimpinan atau prinsip beriman kepada Nabi dan Rasul diantaranya memiliki kepedulian terhadap orang lain, membimbing, mengajari, konsisten, serta menyadari kelemahan yang dimiliki. Kemudian, sifat yang terkandung pada prinsip masa depan atau prinsip beriman kepada hari kemudian diantaranya memiliki tujuan terhadap setiap sesuatu yang dilakukan, melakukan sesuatu dengan optimal, bersungguh-sungguh, mampu mengendalikan diri, serta memiliki ketenangan hati. Dan terakhir sifat yang terkandung pada prinsip keteraturan atau prinsip beriman kepada ketentuan Allah diantaranya memiliki kesadaran,

\footnotetext{
${ }^{8}$.Ary Ginanjar Agustian, Rahasia Sukses Membangun Kecerdasan Emosi dan Spiritual (ESQ), dalam Amal Al Ahyadi, Skripsi: Emotional Spitual Quotient (ESQ) Menurut Ary Ginanjar Agustian dan Relevansinya dengan Pembangunan Kompetensi Sosial Kurikulum 2013, (Semarang: UIN Walisongo, 2015), h. 41

9. Ary Ginanjar Agustian, Rahasia Sukses Membangun Kecerdasan Emosi dan Spiritual (ESQ), dalam Amal Al Ahyadi, Skripsi: Emotional Spitual Quotient (ESQ) Menurut Ary Ginanjar Agustian dan Relevansinya dengan Pembangunan Kompetensi Sosial Kurikulum 2013, (Semarang: UIN Walisongo, 2015), h. 41
} 
ketenangan, serta keyakinan dalam berusaha. Karena telah memahami arti penting atau makna dari seluruh proses kehiduoan yang harus dilalui.

\section{Wisata Religi}

Wisata religi yang dimaksud yaitu lebih mengarah kepada wisata ziarah. Secara etimologi ziarah berasal dari bahasa Arab yaitu zaaru, yazuuru, Ziyarotan. Ziarah yang dapat diartikan kunjungan, baik kepada orang yang masih hidup maupun yang sudah meninggal. Namun, dalam pemahaman masyarakat yaitu melakukan kunjungan ke kuburan atau makam orang yang telah meninggal. Kegiatan tersebut sering disebut dengan ziarah kubur. Dalam Islam, ziarah kubur dianggap sebagai perbuatan sunah yaitu apabila dikerjakan mendapat pahala dan apabila ditinggalkan tidak berdosa.

Ruslan mengatakan bahwa Praktik ziarah sebenarnya telah ada sebelum Islam, namun dilebih-lebihkan sehingga Rasulullah sempat melarangnya. Tradisi ini pun dihidupkan kembali bahkan dianjurkan untuk mengingat kematian. ${ }^{10}$

\section{Bentuk-bentuk Wisata Religi}

Menurut Suryono, wisata religi dimaknai sebagai kegiatan wisata ke tempat yang memiliki makna khusus, tempat-tempat yang biasa dikunjungi dalam wisata religi tersebut, diantaranya Masjid, sebagai tempat pusat keagamaan dimana masjid digunakan untuk beribadah sholat, i'tikaf, adzan dan iqomah. Kemudian, Makam dalam tradisi Jawa, tempat yang mengandung kesakralan. Makam dalam bahasa Jawa merupakan penyebutan yang lebih tinggi (hormat) pesarean, sebuah kata benda yang berasal dan sare, (tidur). Dalam pandangan tradisional, makam merupakan tempat peristirahatan. ${ }^{11}$ Selanjutnya, pada saat ini bentuk wisata religi tidak hanya dapat melihat atau berziarah ke masjid atau makam saja melainkan adanya sesuatu yang dapat dilakukan misalnya pengajian. Menurut Anngit Caroko, Pengajian merupakan suatu kegiatan belajar ilmu agama bersama orang yang memiliki ilmu agama tersebut. ${ }^{12}$

Menurut Ruslan tujuan wisata religi mempunyai makna yang dapat dijadikan pedoman untuk menyampaikan syiar islam di seluruh dunia, dijadikan sebagai pelajaran,

${ }^{10}$. Ahsana Mustika Ati, skripsi : Pengelolaan Wisata Religi; Studi Kasus Makam Sultan Hadiwijaya Untuk Pengembangan Dakwah, (Semarang: Institut Agama Islam Walisongo, 2011) h. 30, 11/01/17 20.00 WIB

${ }^{11}$. Ahsana Mustika Ati, skripsi : Pengelolaan Wisata Religi; Studi Kasus Makam Sultan Hadiwijaya Untuk Pengembangan Dakwah, (Semarang: Institut Agama Islam Walisongo, 2011), h. 33

${ }^{12}$.Anggit Caroko, artikel; Manfaat Mengikuti Pengajian, diakses dari http://anggitcaroko04.blogspot.co.id/2013/12/manfaat-mengikuti-pengajian_2.html pada tanggal 12/06/2017 $00.00 \mathrm{WIB}$ 
untuk mengingat ke-Esaan Allah. Mengajak dan menuntun manusia supaya tidak tersesat kepada syirik atau mengarah kepada kekufuran. ${ }^{13}$

Abidin menyebutkan bahwa tujuan ziarah kubur adalah Islam mensyariatkan ziarah kubur untuk mengambil pelajaran dan mengingatkan akan kehidupan akhirat dengan syarat tidak melakukan perbuatan yang membuat Allah murka, seperti minta restu dan doa dari orang yang meninggal, Mengambil manfaat dengan mengingat kematian orang-orang yang sudah wafat dijadikannya pelajaran bagi orang yang hidup bahwa kita akan mengalami seperti apa yang mereka alami yaitu kematian, Orang yang meninggal diziarahi agar memperoleh manfaat dengan ucapan doa dan salam oleh para peziarah tersebut dan mendapatkan ampunan. ${ }^{14}$ Tujuan dari melakukan wisata religi tidak hanya ketiga tujuan yang telah dipaparkan tersebut, melaikan terdapat salah satu tujuan yang lainnya yaitu untuk meningkatkan keimanan lahir serta bathin seseorang.

\section{Makam Keramat Masjid Ar-Riyadh Kwitang}

Salah Satu Situs Wisata Religi yaitu Makam Keramat Masjid Ar-Riyadh Kwitang yang dapat dikenal dengan Masjid Ar-Riyadh adalah sebuah masjid bersejarah yang berada di depan Jalan Kembang VI No.4A Rt 01/02, Kwitang, Jakarta Pusat. Secara geografis, Masjid ini terletak di tengah-tengah permukiman penduduk yang cukup padat sehingga masjid ini tidak memiliki halaman yang luas. ${ }^{15}$

Masjid ini kurang lebih dibangun pada tahun 1911 oleh Habib Ali dengan nama AlMakmur, dahulunya masjid ini hanyalah sebuah surau/musholla/langgar yang berbentuk panggung. Kemudian, pada tahun 1960-an masjid ini direnovasi, selesai pada tahun 1963 dengan berganti nama menjadi Masjid Quwwatul Ummah yang diberikan langsung oleh presiden pertama yaitu Bapak Soekarno. Kemudian, masjid ini berganti nama lagi menjadi Ar-Riyadh yang artinya taman atau kebun. Nama tersebut sesuai dengan perintah dari gurunya Habib Ali yang ada di Timur Tengah.

Makam Keramat Habib Ali Al-Habsyi merupakan salah satu destinasi wisata religi yang dikunjungi oleh wisatawan lokal maupun wisatawan mancanegara yang berasal dari Hadramaut, Singapura, China, Malaysia, dan sebagainya. Jumlah wisatawan atau pengunjung yang sebagian besar adalah peziarah dapat mencapai ribuan orang yang datang setiap minggunya.

\footnotetext{
${ }^{13}$.Ahsana Mustika Ati, Skripsi : Pengelolaan Wisata Religi; Studi Kasus Makam Sultan Hadiwijaya Untuk Pengembangan Dakwah, (Semarang: Institut Agama Islam Walisongo, 2011) h. 34,

${ }^{14}$.Zainal Abidin, Alam Kubur dan Seluk Beluknya, (Solo : Rineka Cipta, 1991) h. 64

${ }^{15}$. http://bujangmasjid.blogspot.co.id/2012/04/masjid-jami-al-riyadh-kwitang-jakarta.html?m=1 diakses pada tanggal 09/06/2017 20.00 WIB
} 


\section{Wisata religi dapat meningkatkan spiritualitas}

Wisata religi terbukti dapat meningkatkan spiritulaitas para peziarah yang datang ke Makam Keramat Masjid Ar-Riyadh Kwitang Jakarta dilihat dari enam indikator peningkatan spiritualitas yang berlandaskan pada prinsip rukun iman menurut teori ESQ Ary Ginanjar Agustian.

Berdasarkan hasil wawancara dengan lima responden dapat ditemukan ada dua responden yanag mengatakan bahwa proses berziarah dan mengikuti pengajian dengan khusyuk, serta merenung yang dilakukan oleh peziarah di Makam Keramat Kwitang sampai munculnya suara hati untuk menyampaikan sesuatu dari yang telah dilakukan sebagai petunjuk yang baik merupakan tanda adanya peningkatan keimanan kepada Allah SWT, dengan cerminan prinsip-prinsip dasar dalam kehidupan seperti memilikinya rasa percaya diri, mampu menyelesaikan permasalahan dengan solusi yang tepat, serta selalu melakukan perubahan-perubahan ke arah yang lebih baik. Misalnya, salah satu responden dahulunya tidak memiliki rasa percaya diri ketika berinteraksi dengan orang banyak, setelah rutin berzirah dan mengikuti pengajian di Makam Keramat Kwitang Jakarta serta merenunginya, kini telah memiliki kepercayaan diri dalam berinteraksi dengan orang banyak. Sedangkan, salah satu responden lagi dahulunya tidak memiliki rasa percaya diri untuk menjadi seorang tukang urut bayi sebagai jalan penyelesaian dari permasalahan ekonomi yang dialami. Namun, setelah rutin berzirah dan mengikuti pengajian di Makam Keramat Kwitang Jakarta serta merenunginya, kini telah memiliki rasa percaya diri serta menikmati profesinya sebagai tukang urut/pijat.

Kedua, tanda adanya peningkatan keimanan kepada malaikat, dengan cerminan prinsip-prinsip kepercayaan dalam kehidupan seperti memilikinya rasa suka memberi, selalu menolong sanak saudara atau kerabat bahkan sesama yang sedang mengalami kesulitan, serta tidak mudah berperasangka buruk kepada orang lain. Misalnya, dahulu sebelum sering berziarah dan mengikuti pengajian di Makam Keramat Kwitang Jakarta, kedua responden merasa ragu atau tidak percaya ketika hendak membantu sanak saudara atau anaknya yang sedang mengalami kesulitan. Namun, setelah sering berziarah dan mengikuti pengajian di Makam Keramat Kwitang Jakarta, mereka tidak lagi merasa ragu ketika hendak menolong orang lain yang sedang dalam kesulitan dengan pemikiran berniat untuk menolong dengan keikhlasan.

ketiga, dalam peningkatan keimanan kepada kitab Allah melalui proses berziarah dan mengikuti pengajian dengan khusyuk, serta merenung yang dilakukan oleh peziarah di Makam Keramat Kwitang sehingga dapat munculnya suara hati untuk menyampaikan 
sesuatu dari yang telah dilakukan sebagai petunjuk yang baik merupakan tanda adanya peningkatan keimanan kepada Kitab Allah, dengan cerminan prinsip-prinsip pembelajaran dalam kehidupan seperti memiliki kebiasaan membaca buku dan membaca situasi dengan cermat, berpikir kritis dan mendalam, selalu mengevaluasi pemikirannya, bersikap terbuka, serta memiliki pedoman yang kuat dalam belajar yaitu al-Qur'an.

Perubahan-perubahan yang terjadi pada dua responden tersebut misalnya, dahulu sebelum sering berziarah dan mengikuti pengajian di Makam Keramat Kwitang Jakarta, kedua responden masih jarang atau sulit untuk membaca Al-Quran pada setiap harinya, serta cara berfikir yang masih sempit. Namun, setelah sering berziarah dan mengikuti pengajian di Makam Keramat Kwitang Jakarta, mulai terbuka mata hati pikiran mereka, kini mereka dapat melakukan kebiasaan baik yaitu membaca kitab suci Al-Quran dalam kehidupan sehari-hari, serta mereka mampu membaca situasi dan kondisi sesuai dengan kemampuan mereka masing-masing.

Keempat, melalui proses berziarah dan mengikuti pengajian dengan khusyuk, serta merenung yang dilakukan oleh peziarah di Makam Keramat Kwitang sehingga dapat munculnya suara hati untuk menyampaikan sesuatu dari yang telah dilakukan sebagai petunjuk yang baik merupakan adanya tanda peningkatan keimanan kepada Nabi dan Rasul Allah, dengan cerminan prinsip-prinsip kepemimpinan dalam kehidupan seperti memiliki rasa peduli kepada orang lain, membimbing, mengajari, konsisten, serta menyadari kelemahan yang dimiliki dengan landasan ketakwaan kepada Allah SWT.

Perubahan-perubahan yang terjadi pada dua responden tersebut misalnya, dahulu sebelum sering berziarah dan mengikuti pengajian di Makam Keramat Kwitang Jakarta, kedua responden masih kurang menyadari kalau diri mereka masing-masing memiliki kelemahan atau kekurangan, masih enggan untuk berbagi ilmu dengan orang lain yang belum mengerti dan kurang memperdulikan Pendidikan agama atau kurang membimbing anak-anak mereka tentang aturan-aturan agama. Namun, setelah sering berziarah dan mengikuti pengajian di Makam Keramat Kwitang Jakarta, mulai terbuka mata hati serta pikiran mereka, kini mereka dapat melakukan kebiasaan baik yaitu mau berbagi ilmu pengetahuan yang dimiliki, menyadari akan kelemahan dan kekurangan agar selalu mengevaluasi diri, serta membimbing anak-anak mereka ke arah yang lebih baik lagi dari sebelumnya dengan Pendidikan atau pemahaman agama.

Kelima, melalui proses berziarah dan mengikuti pengajian dengan khusyuk, serta merenung yang dilakukan oleh peziarah di Makam Keramat Kwitang sehingga dapat munculnya suara hati untuk menyampaikan sesuatu dari yang telah dilakukan sebagai 
petunjuk yang baik merupakan tanda adanya peningkatan keimanan kepada hari kemudian, dengan cerminan prinsip-prinsip masa depan dalam kehidupan seperti memiliki tujuan terhadap setiap sesuatu yang dilakukan, melakukan sesuatu dengan optimal, bersungguhsungguh, mampu mengendalikan diri, serta memiliki ketenangan hati. Hal tersebut karena adanya kesadaran serta keyakinan akan "hari pembelasan".

Perubahan-perubahan yang terjadi pada dua responden tersebut misalnya, dahulu sebelum sering berziarah dan mengikuti pengajian di Makam Keramat Kwitang Jakarta, kedua responden tersebut masih kurang efektif dalam menggunakan waktu sehingga pekerjaan yang dilakukan tidak dapat terselesaikan dengan optimal yang dikarenakan tidak adanya kesungguhan dalam mengerjakan suatu pekerjaan trersebut, masih sulit dalam meredam atau mengendalikan emosi. Namun, setelah sering berziarah dan mengikuti pengajian di Makam Keramat Kwitang Jakarta, mulai terbuka mata hati serta pikiran mereka, kini mereka dapat melakukan kebiasaan baik yaitu lebih bersungguh-sungguh dalam mengerjakan suatu pekerjaan dengan menghargai waktu menggunakannya secara bijaksana sehingga pekerjaan yang dilakukan dapat hasil yang otimal.

Keenam, melalui proses berziarah dan mengikuti pengajian dengan khusyuk, serta merenung yang dilakukan oleh peziarah di Makam Keramat Kwitang sehingga dapat munculnya suara hati untuk menyampaikan sesuatu dari yang telah dilakukan sebagai petunjuk yang baik merupakan tanda adanya peningkatan keimanan kepada ketentuan Allah, dengan cerminan prinsip-prinsip masa depan dalam kehidupan seperti memiliki kesadaran, ketenangan, serta keyakinan dalam berusaha. Karena telah memahami arti penting atau makna dari seluruh proses kehidupan yang harus dilalui.

Perubahan-perubahan yang terjadi pada dua responden tersebut misalnya, dahulu sebelum sering berziarah dan mengikuti pengajian di Makam Keramat Kwitang Jakarta, kedua responden tersebut masih kurang yakin akan setiap usaha yang dilakukan serta tidak menghiraukan segala proses kehidupan yang terjadi. Namun, setelah sering berziarah dan mengikuti pengajian di Makam Keramat Kwitang Jakarta, mulai terbuka mata hati serta pikiran mereka, kini mereka dapat lebih yakin dengan kemampuan mereka sendiri ketika melakukan sesuatu, dan lebih menghargai akan setiap proses yang terjadi dalam kehidupan.

Hal ini sejalan dengan yang dikemukakan oleh Ary Ginanjar Agustian bahwa keimanan kepada Allah dapat dirasakan saat seseorang melakukan sesuatu sampai hatinya berkata. Dimana dalam hal tersebut seseorang mulai paham dan mendengarkan kata 
hatinya bahwa segala tindakan dan keputusan yang diambil berdasarkan kecintaan kepada Allah SWT. ${ }^{16}$

Seseorang dapat merenungkan segala yang ada dalam dirinya yaitu cara menyelesaikan suatu masalah dengan memberikan solusi yang tepat, melakukan sesuatu dengan rasa percaya diri, serta membangkitkan semangat untuk melakukan perubahanperubahan ke arah yang lebih baik dari sebelumnya.

Suara hati merupakan sebuah kesadaran atau pusat pendirian yang berasal dari kedalaman hati. Suara hati tersebut dapat diperoleh salah satunya dengan proses perenungan yang dilakukan peziarah saat berziarah dan mengikuti pengajian di Makam Keramat Masjid Ar-Riyadh Kwitang.

\section{Penutup}

Berdasarkan hasil peenlitian yang diperoleh, dapat disimpukan bahwa kegiatan spiritualitas yang dilakukan di Makam Keramat Masjid Ar-Riyadh Kwitang dapat meningkatkan spiritualitas para peziarah. Kegiatan spiritual tersebut diantaranya berziarah ke Makam Habib Ali Al-Habsyi ( Habib Ali Kwitang) dengan membaca yasin, tahlil, tahmid bahkan doa-doa khusus yang dipanjatkan para peziarah untuk mendapatkan keberkahan serta keridhaan Allah SWT, serta mengikuti pengajian rutin mingguan setiap Hari Minggu Pagi yang berlangsung kurang lebih selama dua setengah jam dengan isi kegiatan berupa tausiah-tausiah keagamaan dari para tokoh agama seperti habaib, dan ulama-ulama besar lainnya.

Berdasarkan hasil penelitian yang diperoleh dari beberapa responden atau peziarah yang telah sering datang ke Makam Keramat Masjid Ar-Riyadh Kwitang Jakarta untuk berziarah maupun mengikuti pengajian rutin mingguan, menunjukkan bahwa ada dua dari lima responden yang mengalami peningkatan spiritualitas dengan baik. Karena kedua responden tersebut telah dapat merasakan ketenangan jiwa, sehingga sikap serta perilaku terhadap orang lain lebih baik dan peduli akan keadaan orang lain.

Sebelum sering melakukan ziarah dan mengikuti pengajian, kedua responden kerap kali tidak terkontrol emosinya, tidak sabaran, tidak pernah bersyukur, tidak peduli dengan orang lain, sering melakukan kesalahan dan memiliki banyak masalah. Sehingga tidak

\footnotetext{
${ }^{16}$ Ary Ginanjar Agustian, Rahasia Sukses Membangun Kecerdasan Emosi dan Spiritual (ESQ), dalam Amal Al Ahyadi, Skripsi: Emotional Spitual Quotient (ESQ) Menurut Ary Ginanjar Agustian dan Relevansinya dengan Pembangunan Kompetensi Sosial Kurikulum 2013, (Semarang: UIN Walisongo, 2015), h. 51
} 
dapat merasakan ketenangan jiwa dalam menjalani kehidupan. Seiring berjalannya waktu, dan sering melakukan kegiatan wisata religi ke Makam Keramat Masjid Ar-Riyadh Kwitang Jakarta. Lama kelamaan sikap dan perilaku yang kurang baik tersebut dapat berubah menjadi lebih baik. Kedua responden tersebut beranggapan bahwa yang membuat mereka memiliki perubahan dari tidak baik menjadi lebih baik, dari kurang atau tidak peduli menjadi lebih peduli kepada orang lain, yaitu karena mereka sering instropeksi diri terutama saat sedang berziarah dan mengikuti pengajian dengan khusyuk sampai berdiam diri untuk beberapa saat.

Perubahan yang terjadi dalam diri mereka ditandai dengan adanya enam prinsip yang berlandaskan pada nilai rukun iman yang meliputi beriman kepada Allah sebagai Prinsip Dasar, beriman kepada malaikat sebagai prinsip kepercayaan, beriman kepada kitab Allah sebagai prinsip pembelajaran, beriman kepada Nabi dan Rasul sebagai prinsip kepemimpinan, beriman kepada hari kemudian sebagai prinsip masa depan, beriman kepada ketentuan Allah sebagai prinsip keteraturan.

Sifat yang terkandung pada prinsip dasar atau prinsip beriman kepada Allah diantaranya memiliki kepercayaan diri tinggi, integritas kuat, sikap bijaksana, memiliki motivasi tinggi. Kemudian, sifat yang terkandung pada prinsip kepercayaan atau prinsip beriman kepada malaikat diantaranya memiliki tingkat kualitas diri tinggi, komitmen kuat, suka memberi, suka menolong, dan sikap saling percaya. Selanjutnya, sifat yang terkandung pada prinsip pembelajaran atau prinsip beriman kepada kitab Allah diantaranya memiliki kebiasaan membaca buku dan membaca situasi dengan cermat, berpikir kritis dan mendalam, selalu mengevaluasi pemikirannya, bersikap terbuka.

Lalu, sifat yang terkandung pada prinsip kepemimpinan atau prinsip beriman kepada Nabi dan Rasul diantaranya memiliki kepedulian terhadap orang lain, membimbing, mengajari, konsisten, serta menyadari kelemahan yang dimiliki. Kemudian, sifat yang terkandung pada prinsip masa depan atau prinsip beriman kepada hari kemudian diantaranya memiliki tujuan terhadap setiap sesuatu yang dilakukan, melakukan sesuatu dengan optimal, bersungguh-sungguh, mampu mengendalikan diri, serta memiliki ketenangan hati. Dan terakhir sifat yang terkandung pada prinsip keteraturan atau prinsip beriman kepada ketentuan Allah diantaranya memiliki kesadaran, ketenangan, serta keyakinan dalam berusaha. Karena telah memahami arti penting atau makna dari seluruh proses kehiduoan yang harus dilalui. 
Jadi, dapat disimpulkan bahwa peningkatan spiritualitas dapat ditingkatkan melalui kegiatan wisata religi di Makam Keramat Kwitang Jakarta Pusat. Karena dari lima responden dapat ditemukan dua responden yang mengalami peningkatan spiritualitas dengan baik, sehingga dapat diperolehnya ketenangan jiwa. Sedangkan, dari kelima responden tersebut yang dominan muncul yaitu meningkatnya iman kepada Allah sebagai landasan dapat terbentunya prinsip dasar kehidupan dengan baik. Hal ini sesuai dengan penjelasan mengenai peningkatan spiritualitas merupakan proses kemajuan atau perubahan yang terjadi dari keadaan yang negatif menjadi positif ditandai dengan adanya peningkatan pada aspek rukun iman dalam diri pengunjung atau peziarah yang meliputi beriman kepada Allah sebagai Prinsip Dasar dalam kehidupan seperti memilikinya rasa percaya diri, mampu menyelesaikan permasalahan dengan solusi yang tepat, serta selalu melakukan perubahan-perubahan ke arah yang lebih baik, beriman kepada malaikat sebagai prinsip kepercayaan dalam kehidupan seperti memilikinya rasa suka memberi, selalu menolong sanak saudara atau kerabat bahkan sesama yang sedang mengalami kesulitan, serta tidak mudah berperasangka buruk kepada orang lain, beriman kepada kitab Allah sebagai prinsip pembelajaran dalam kehidupan seperti memiliki kebiasaan membaca buku dan membaca situasi dengan cermat, berpikir kritis dan mendalam, selalu mengevaluasi pemikirannya, bersikap terbuka, serta memiliki pedoman yang kuat dalam belajar yaitu al-Qur'an, beriman kepada Nabi dan Rasul sebagai prinsip kepemimpinan dalam kehidupan seperti memiliki rasa peduli kepada orang lain, membimbing, mengajari, konsisten, serta menyadari kelemahan yang dimiliki dengan landasan ketakwaan kepada Allah SWT, beriman kepada hari kemudian sebagai prinsip masa depan dalam kehidupan seperti memiliki tujuan terhadap setiap sesuatu yang dilakukan, melakukan sesuatu dengan optimal, bersungguh-sungguh, mampu mengendalikan diri, serta memiliki ketenangan hati. Hal tersebut karena adanya kesadaran serta keyakinan akan "hari pembelasan", dan beriman kepada ketentuan Allah sebagai prinsip keteraturan dalam kehidupan seperti memiliki kesadaran, ketenangan, serta keyakinan dalam berusaha. Karena telah memahami arti penting atau makna dari seluruh proses kehidupan yang harus dilalui. 


\section{E. Daftar Pustaka}

Abidin, Zainal. Alam Kubur dan Seluk Beluknya, Solo : Rineka Cipta, 1991.

Agustian, Ary Ginanjar. Rahasia Sukses Membangun Kecerdasan Emosi dan Spiritual (ESQ), dalam Amal Al Ahyadi, Skripsi: Emotional Spitual Quotient (ESQ) Menurut Ary Ginanjar Agustian dan Relevansinya dengan Pembangunan Kompetensi Sosial Kurikulum 2013, Semarang: UIN Walisongo, 2015.

Ahsana Mustika Ati, skripsi : Pengelolaan Wisata Religi; Studi Kasus Makam Sultan Hadiwijaya Untuk Pengembangan Dakwah, Semarang: Institut Agama Islam Walisongo, 2011.

Anggit Caroko, artikel; Manfaat Mengikuti Pengajian, diakses dari http://anggitcaroko04.blogspot.co.id/2013/12/manfaat-mengikuti-pengajian_2.html

Artikel; Pengertian Peningkatan Menurut Para Ahli, diakses dari http://www.duniapelajar.com/2014/08/08/pengertian-peningkatan-menurut-para$\underline{\text { ahli/ }}$

Departemen Agama RI, Jakarta : 1994.

http://bujangmasjid.blogspot.co.id/2012/04/masjid-jami-al-riyadh-kwitangjakarta.html?m=1

Martokoesoemo, Priatno H. Spiritual Thinking, Jakarta: Mizania, 2007.

Pusat Bahasa, KBBI, Jakarta: Balai Pustaka, 2007.

Selamat, Muhammad Isa. Penawar Jiwa \& Pikiran, Jakarta : Kalam Mulia, 2005. 